\title{
UPAYA PEMBERDAYAAN MASYARAKAT LOKAL PADA DAYA TARIK WISATA LEMO, KECAMATAN MAKALE UTARA, KABUPATEN TANA TORAJA
}

\author{
Seriany Tonglo ${ }^{\mathrm{a}, 1}$, I Made Adikampanaa, 2 \\ 1seriozan1@gmail.com, 2adikampana@gmail.com
}

a Program Studi S1 Destinasi Pariwisata, Fakultas Pariwisata,Universitas Udayana, Jl. Dr. R. Goris, Denpasar, Bali 80232 Indonesia

\begin{abstract}
The purposed of this paper is to find out the empowerment efforts by government to developing the local communities at tourist attraction of Lemo, especially in the field of tourism. Thus, it's expected the local communities can play an active role in developing of tourism industry in their place.

The author directly go to the field for observation and data collection in order to know the existing problems. The collection of data used in this study were obtained through observation techniques, documentation, library research, and interviews on informers. Informers are deemed to know about the problems in community empowerment, by using a qualitative descriptive analysis.

The author found out that there are many constraints faced by the local communities such the lack of knowledge of the local communities in the field of tourism and the lack of the number of people who can speak foreign languages, so it's need participation from government and other related sector in overcoming the obstacles encountered by the community.
\end{abstract}

Keywords: Community empowerment, Tourist Attraction of Lemo

\section{PENDAHULUAN}

Kabupaten Tana Toraja merupakan salah satu dari beberapa kabupaten yang ada di Indonesia yang terkenal akan wisata budayanya yang unik dan wisata alamnya yang mempesona. Kabupaten Tana Toraja juga memiliki berbagai macam potensi dan daya tarik wisata di setiap wilayahnya. Salah satu daya tarik wisata yang dimiliki Kabupaten Tana Toraja adalah Daya Tarik Wisata Lemo

Daya Tarik Wisata Lemo merupakan situs pemakaman para kepala suku maupun tokoh - tokoh masyarakat di Kabupaten Tana Toraja pada masa lampau. Deretan "tau-tau" menjadi 'penjaga' makam-makam tersebut. Daya Tarik Wisata Lemo merupakan salah satu daya tarik wisata yang ada di Kabupaten Tana Toraja yang sering dikunjungi wisatawan lokal maupun mancanegara.

Daya Tarik Wisata Lemo merupakan sebuah daya tarik wisata yang sangat potensial untuk lebih dikembangkan kedepannya. Sehingga, diharapkan seluruh sektor yang terkait dapat turut berpean dalam perkembangan pariwisata di Daya Tarik Wisata Lemo.

Masyarakat lokal merupakan salah satu sektor penting yang wajib turut serta berperan aktif dalam perkembangan pariwisata di Daya Tarik Wisata Lemo. Tingkat kemampuan dan pengetahuan tentang kepariwisataan masyarakat di sekitar
Daya Tarik Wisata Lemo masih sangat minim dan kurang. Ini menunjukkan bahwa masyarakat masih belum berdaya dan menjadi kendala dalam perkembangan pariwisata di Daya Tarik Wisata Lemo.

Hal inilah yang membuat penulis tertarik untuk membahas tentang pemberdayaan masyarakat di daya tarik wisata Lemo, Kabupaten Tana Toraja. Hal ini juga dilatarbelakangi oleh minimnya sumber daya kepariwisataan yang ada pada daya tarik wisata Lemo di Kabupaten Tana Toraja sehingga perlu adanya penulisan lebih lanjut dalam pemberdayaan masyarakat di Daya Tarik Wisata Lemo, Kabupaten Tana Toraja Provinsi Sulawesi Selatan.

Sehingga, berdasarkan hal tersebut tulisan ini bertujuan untuk membahas pemberdayaan masyarakat di Daya Tarik Wisata Lemo, Kabupaten Tana Toraja. Adapun pokok rumusan masalah pada penulisan ini adalah : 1 . Bagaimana upaya pemberdayaan yang dilakukan oleh pihak pemerintah dan pengelola dalam mengelola Daya Tarik Wisata Lemo dan 2. kendala yang dihadapi oleh pihak pemerintah, pengelola dan masyarakat dalam upaya pemberdayaan masyarakat. 


\section{TINJAUAN PUSTAKA}

\subsection{Daya Tarik Wisata}

Daya Tarik Wisata adalah segala sesuatu yang memiliki keunikan, keindahan, dan nilai yang berupa keanekaragaman kekayaan alam, budaya, dan hasil buatan manusia yang menjadi sasaran atau tujuan kunjungan wisatawan (UU Kepariwisataan no.10 tahun 2009). Definisi lain dari daya tarik wisata adalah segala sesuatu yang menarik dan bernilai untuk dikunjungi (Pendit,1994). Jadi, dapat disimpulkan bahwa daya tarik wisata adalah segala sesuatu yang memiliki keunikan, keindahan, dan nilai yang berupa keanekaragaman kekayaan alam, budaya, dan hasil buatan manusia yang menarik dan bernilai untuk dikunjungi.

\subsection{Pemberdayaan Masyarakat}

Pemberdayaan masyarakat adalah bentuk upaya untuk memandirikan masyarakat lewat perwujudan potensi yang dimiliki (Sumodiningrat,1999). Adapun masyarakat terdiri dari dua kelompok yang saling terkait, yaitu masyarakat sebagai pihak yang diberdayakan dan pihak lainnya sebagai pihak yang memberdayakan.

Masyarakat merupakan keseluruhan kompleks kehidupan manusia yang luas. keseluruhan kompleks ini dikatakan sebagai suatu sistem yang merupakan unsur-unsur, komponen-komponen yang berangkai dan saling berkaitan dan memiliki ketergantungan secara fungsional dalam rangka mencapai suatu tujuan, yang dalam sistemnya diperlukan ada kerjasama yang seimbang, selaras dan serasi yang mengarah pada integrasi (Soekanto,1990).

\section{METODE}

Guna memperjelas variabel-variabel yang digunakan dalam penulisan ini serta untuk membahas ruang lingkup permasalahan yang dibahas, maka berikut ini akan dijelaskan variabel yang terdapat dalam permasalahan yang akan dibahas.

\subsection{Lokasi Penulisan}

Lokasi penulisan ini berada di Daya Tarik Wisata Lemo, Kecamatan Makale Utara Kabupaten Tana Toraja, Provinsi Sulawesi Selatan.

\subsection{Teknik Pengumpulan Data}

Dalam pengumpulan data-data yang diperlukan dalam penulisan ini menggunakan beberapa cara, yaitu :
1. Observasi

Observasi merupakan teknik pengumpulan data dengan cara mengamati, meneliti kejadian yang sedang berlangsung ( Kusmayadi dan Endar, 2000 :84).

2. Wawancara

Teknik pengumpulan data melalui wawancara mendalam yang dibantu oleh pedoman wawancara, serta observasi lansung di lapangan (Bungin,2007) pada informan kunci dan informan pangkal, sesuai dengan kriteria yang telah ditentukan. Melalui wawancara yang mendalam ini penulis dapat memperoleh data - data, gambaran, keterangan, pandangan dan pengalaman secara lisan tentang berbagai hal yang berkaitan dengan pemberdayaan masyarakat di Daya Tarik Wisata Lemo

3. Studi Kepustakaan

Teknik pengumpulan data melalui literatur, dokumen, laporan, buku yang masih berhubungan dengan penulisan ini. Kemudian dipelajari untuk mendapatkan data - data yang berkaitan.

4. Studi Dokumentasi

Teknik pengumpulan data dengan melakukan dokumentasi dengan menggunakan kamera digital di lokasi penulisan. Melalui studi dokumentasi penulis mengumpulkan data melalui dokumentasi baik yang bentuk tulisan,gambar,atau karyakarya monumental seseorang yang berhubungan dengan penulisan ini dan yang dibutuhkan dalam menyusun hasil penulisan.

\subsection{Teknik Pemilihan Informan}

Dalam pembahasanini penulis mengambil beberapa informan di lokasi penulisan. Informan - informan tersebut adalah Kepala Dinas Kebudayaan dan Pariwisata Kabupaten Tana Toraja, Kepala Pengelola Daya Tarik Wisata Lemo, masyarakat Desa Lemo dan pedagang souvenir di Daya Tarik Wisata Lemo Kecamatan Makale Utara.

\subsection{Teknik Analisis Data}

Analisis yang digunakan adalah analisis deskriptif kualitatif. Analisis deskriptif kualitatif adalah analisis data yang mempunyai tujuan untuk menggambarkan serta menguraikan secara jelas fenomena dan hubungan antar fenomena secara sistematis, 
factual dan akurat ( Kusmayadi dan Endar, $2000: 29$ )

\section{HASIL DAN PEMBAHASAN}

\subsection{Gambaran Umum Daya Tarik Wisata Lemo}

Daya Tarik Wisata Lemo terletak di

Desa Lemo, Kecamatan Makale Utara, Kabupaten Tana Toraja. Luas wilayah Kecamatan Makale Utara sebesar 26.08 km² $^{2}$ Dapat ditempuh menggunakan kendaraan roda empat dan roda dua, dengan jarak tempuh dari pusat kota sepanjang $6 \mathrm{~km}$ (Badan Pusat Statistik Kabupaten Tana Toraja 2012).

Masyarakat yang ada di Daya Tarik Wisata Lemo merupakan masyarakat yang hampir secara keseluruhan menggantungkan hidupnya pada sektor pertanian dan sektor peternakan. Masyarakat Desa Lemo umumnya bekerja sebagai petani dan peternak. Hasil tani masyarakat umumnya berupa padi, kopi dan cokelat. Dengan hasil ternak berupa kerbau, babi sapi, kambing dan ayam. Namun, sejak berkembangnya pariwisata di Kabupaten Tana Toraja beberapa dari masyarakat Desa Lemo berprofesi sebagai pedagang souvenir/cinderamata, pegawai dan wiraswasta.

\subsection{Upaya Pemberdayaan Masyarakat pada daya tarik wisata Lemo}

Upaya pemberdayaan masyarakat lokal pada Daya Tarik Wisata Lemo adalah adalah upaya pemberdayaan masyarakat lokal yang dilakukan oleh pihak pemerintah Kabupaten Tana Toraja yang bertujuan agar masyarakat lokal dapat mengembangkan potensi yang dimiliki sehingga masyarakat lokal dapat turut berperan aktif dalam pembangunan kepariwisataan, khususnya yang ada di daya tarik wisata Lemo.

Daya Tarik Wisata Lemo merupakan salah satu daya tarik wisata yang terkenal, yang ada di Kabupaten Tana Toraja dengan tingkat kemampuan dan pengetahuan tentang kepariwisataan masyarakat di sekitar Daya Tarik Wisata Lemo masih sangat minim dan kurang. Ini menunjukkan bahwa masyarakat masih belum berdaya dan kurang berperan aktif dalam pengembangan pariwisata di Daya Tarik Wisata Lemo, hal ini menjadi salah satu kendala dalam perkembangan pariwisata di Daya Tarik Wisata Lemo.
Peran aktif masyarakat lokal diharapkan dapat memiliki keterlibatan langsung dengan pengambilan kebijakan dan pelaksanaan kebijakan langsung yang bertujuan dengan membantu masyarakat lokal untuk meningkatkan kemandirian dan kepedulian dalam memahami dan mengatasi masalah dalam kehidupan sehari - hari. Bentuk upaya pemberdayaan masyarakat yang telah dilakukan oleh pemerintah Kabupaten Tana Toraja seperti :

1. Pembentukkan kelompok - kelompok sadar wisata, kelompok pengrajin, pemahat, dll. Kelompok - kelompok ini yang akan membantu pemerintah dan pengelola dalam usaha pelestarian budaya dan lingkungan, juga turut membantu dalam menangani kunjungan wisatawan ke Daya Tarik Wisata Lemo.

2. Penyuluhan mengenai kepariwisataan dan jenis - jenis usaha baru di bidang pariwisata.

3. Bantuan modal oleh pemerintah maupun stakeholders yang terkait kepada masyarakat yang ingin menjual makanan dan minuman maupun hasil kerajinan tangan/cinderamata.

\subsection{Kendala yang dihadapi dalam pemberdayaan masyarakat lokal di sekitar daya tarik wisata Lemo}

Terdapat beberapa kendala yang dihadapi oleh pihak pemerintah dan pengelola dalam pemberdayaan masyarakat lokal di sekitar daya tarik wisata Lemo yang dapat dikelompokkan menjadi 2, yaitu :

\section{Kendala Internal}

a. Minimnya pengetahuan dan pendidikan kepariwisataan sehingga masyarakat tidak sepenuhnya mengerti tentang perkembangan kepariwisataan dan sistem - sistem yang terkait didalamnya.

b. Masih ada masyarakat yang belum mengetahui informasi mengenai bantuan dari pemerintah sehingga masih belum dapat turut serta berperan dalam pembangunan kepariwisataan.

c. Minimnya jumlah masyarakat lokal yang dapat berbahasa asing sehingga terkadang wisatawan yang datang menggunakan guide dari luar yang dapat membantu mereka sehingga 
pemasukkan yang didapat pun hanya

dari pajak retribusi parkir/masuk dan hasil penjualan souvenir/cinderamata.

\section{Kendala Eksternal}

1. Minimnya lembaga - lembaga pendidikan negeri maupun swasta yang memberikan pengajaran tentang kepariwisataan sehingga membuat minimnya sumber daya manusia pariwisata, khususnya yang berasal dari masyarakat lokal.

2. Minimnya investor swasta yang yang membuat masyarakat hanya bergantung pada pihak pemerintah dalam memberikan modal/bantuan dalam mengembangkan usaha dan potensi yang dimiliki.

\section{SIMPULAN DAN SARAN \\ 5.1 Simpulan}

Pemerintah telah melaksanakan upaya pemberdayaan pada masyarakat yang ada di sekitar Daya Tarik Wisata Lemo seperti pembentukkan kelompok - kelompok sadar wisata, kelompok pengrajin, pemahat dll. Penyuluhan mengenai kepariwisataan dan jenis jenis usaha baru di bidang pariwisata dan pemerintah juga memberikan bantuan modal kepada masyarakat yang ingin menjual makanan dan minuman maupun hasil kerajinan tangan/cinderamata di sekitar lokasi Daya Tarik Wisata Lemo. Namun pelaksanaan bentuk pemberdayaan ini masih kurang maksimal dikarenakan masih adanya kendala - kendala yang dihadapi oleh pemerintah maupun masyarakat lokal,

Kendala - kendala yang dihadapi ada dua yaitu kendala internal dan kendala eksternal. Kendala internal yang ada seperti rendahnya pengetahuan dan pendidikan masyarakat lokal tentang kepariwisataan sehingga masyarakat tidak sepenuhnya mengerti tentang perkembangan kepariwisataan dan sistem - sistem yang terkait didalamnya sehingga terkadang masyarakat dirugikan karena minimnya pengetahuan tersebut. Masih ada masyarakat yang belum mengetahui informasi mengenai bantuan dari pemerintah dan juga minimnya jumlah masyarakat lokal yang dapat berbahasa asing sehingga terkadang wisatawan yang datang menggunakan guide dari luar kota/daerah yang dapat membantu mereka sehingga pemasukkan yang didapat masyarakat lokal pun hanya bergantung dari pajak retribusi parkir/masuk dan hasil penjualan souvenir/cinderamata.

Berdasarkan kendala eksternal meliputi minimnya lembaga - lembaga pendidikan dalam bidang kepariwisataan yang ada di Kabupaten Tana Toraja yang berakibat rendahnya pengetahuan masyarakat mengenai kepariwisataan, dan juga minimnya investor swasta yang membuat masyarakat hanya bergantung pada pemerintah dalam mengembangkan usaha dan potensi yang dimiliki.

\subsection{Saran}

Berdasarkan simpulan di atas penulis dapat berikan beberapa saran yang diharapkan nantinya berguna bagi pihak pemerintah maupun swasta terkait dalam upaya pemberdayaan masyarakat lokal pada Daya Tarik Wisata Lemo, antara lain:

1. Pemerintah mendirikan yayasan maupun lembaga pendidikan yang memiliki fokus pada peningkatan pengetahuan tentang kepariwisataan sehingga dapat menciptakan sumber daya manusia pariwisata yang turut dapat bersaing di era globalisasi sekarang ini.

2. Pemerintah dapat meningkatkan frekuensi tentang pemberian informasi yang terkait bantuan, modal ataupun pelatihan kepada masyarakat lokal sehingga diharapkan seluruh masyarakat lokal dapat turut serta mengembangkan potensi maupun usaha yang dimiliki.

3. Pemerintah sebaiknya membuat kebijakan - kebijakan tambahan pada Daya Tarik Wisata Lemo khususnya dan Kawasan Wisata Tana Toraja pada umumnya mengenai penambahan 
retribusi/pajak pada travel/tour operator yang menggunakan jasa guide dari luar Daya Tarik Wisata Lemo yang bertujuan unutuk pengembangan masyarakat, fasilitas maupun sarana dan prasarana kepariwisataan yang ada di Daya Tarik Wisata Lemo.

\section{DAFTAR PUSTAKA}

Badan Pusat Statistik (BPS) Kabupaten Tana Toraja 2012

Bungin, M. Burhan. 2007. Penelitian Kualitatif, Komunikasi, Ekonomi, Kebijakan Publik, dan Ilmu Sosial Lainnya. Jakarta : Kencana

Kusmayadi dan Endar. Sugiarto. 2000. Metodologi Penelitian dalam Bidang Kepariwisataan. Jakarta: PT. Gramedia Pustaka Utama.

Pendit, Nyoman S.1994. Ilmu Pariwisata : Sebuah Pengantar Perdana. Jakarta : Pradnya Pramita

Soekanto,Soerjono .1990. Sosiologi : Suatu Pengantar. CV Rajawali

Sumodiningrat, Gunawan. 1999. Pemberdayaan Masyarakat Dan Jaring Pengaman Sosial. Jakarta : Gramedia Pustaka Utama

UU Kepariwisataan No.10 Tahun 2009 